\title{
Stability of Vitamin C in Citron Slices in Syrup, and in Citron Bars Boxed and Canned ${ }^{1}$
}

\author{
L. E. Cancel, E. R. de Hernández, and J. M. Rivera-Ortiz ${ }^{2}$
}

\begin{abstract}
Vitamin C stability in citron slices canned in syrup showed a retention of 77 and $73 \%$ of the original amounts of 65 and $110 \mathrm{mg} / 100 \mathrm{~g}$ of product, respectively, during 12.7 months storage. The average vitamin $\mathrm{C}$ destruction was $2.4 \mathrm{mg} / 100 \mathrm{~g} / \mathrm{month}$ and $1.2 \mathrm{mg} / 100 \mathrm{~g} / \mathrm{month}$ respectively for the high and low level vitamin content. There is a difference in the rate of vitamin $\mathrm{C}$ destruction due to the packaging form. Citron fruit bar packed in boxes had after 7 months a retention of $73 \%$ of the original vitamin $\mathrm{C}$ content. The same product packed in cans showed a retention of $84 \%$ after 10 months of storage.
\end{abstract}

\section{INTRODUCTION}

As consumers become more aware of their nutritional needs and as demand is made for national policies, food enrichment will play an increasingly important role in food product development. With the advent of this increased interest in nutrition on the part of both consumers and food processors, it is becoming important to understand what happens to the nutritional value of food products.

Nutrients are destroyed during all stages of processing, in trade, and in the home. Destruction of nutrients is due to sensitivity to $\mathrm{pH}$, oxygen, light, heat, and metals. Some of these factors combine in different ways to form specific systems which influence the stability of nutrients.

Vitamin C has been the object of studies in different products, both natural and processed. Karel and Nickerson (7), Jensen (6), and Vojnovich and Pfeifer (9) studied the stability of ascorbic acid in various dry foods as a function of water content up to about $A_{w}=0.5$ (water activity $=0.5$ ). They have shown that the destruction rate of ascorbic acid increases with increasing moisture content and water activity. Lee and Lubuza (8) confirmed these findings and found that ascorbic acid destruction proceeds more rapidly in the desorption than in the adsorption system, due to a decrease in viscosity and possible dilution in the aqueous phase. They accentuated the importance of the effect caused

${ }^{1}$ Manuscript submitted to Editorial Board September 30, 1975.

${ }^{2}$ Food Scientist, Assistant Food Scientist, and Research Assistant, respectively. Agricultural Experiment Station, University of Puerto Rico, Mayagüez Campus, Río Piedras, P.R. 
by a decrease in viscosity and the resulting increase in mobilization of the reaction species. Bissett and Berry (2) found that ascorbic acid retention in orange juice is influenced by the type of container. Destruction of ascorbic acid in single strength orange juice was fairly rapid ( $80 \%$ retention in 3-4 weeks) in plastic and cardboard containers, while glass afforded better protection (90\% retention). Their work also indicated the effect of temperature on ascorbic acid retention. Frozen concentrated orange juice retained $90 \%$ or more of its vitamin C after 1 year storage when packed even in foil-lined cardboard rectangular cartons and polyethylene lined fiber cylindrical cans. Bolin and Stafford (3) found that in apricot leather production, the drying method had an effect in vitamin C destruction. Sun-dried, shade-dried and dehydrated products exhibited losses of 29,19 , and $12 \%$, respectively. They also demonstrated that sulfur dioxide reduced the loss of vitamin $\mathrm{C}$ during processing and gave added protection during storage.

To specify the vitamin $\mathrm{C}$ content of a product within certain limits, studies are needed to determine the trend of destruction of this vitamin. This study was made for citron slices canned in syrup and for citron fruit bar packed in both boxes and cans.

\section{MATERIALS AND METHODS}

Citron slices in syrup were prepared as described by Cancel and Hernández (4). Vitamin C enrichment was made at different levels to observe the effect, if any, of the concentration. Packing of the lices in syrup was made in plain tin cans, $303 \times 400$. The canned product was stored at an average temperature of $30^{\circ} \mathrm{C}$ with fluctuations from $27^{\circ}$ to $34^{\circ} \mathrm{C}$.

Citron fruit bars were prepared as indicated by Cancel and Hernández (5). Vitamin $\mathrm{C}$ enrichment was made at different concentrations and at the end of the boiling stage.

Fruit bars were packed in C-enameled cans $211 \times 400$ and in cardboard boxes, using $\operatorname{Saran}^{3}$ laminate for the immediate wrapping of the product. Boxes containing the fruit bar were stored at an average temperature of $22^{\circ} \mathrm{C}$, varying from $21.6^{\circ}$ to $22.7^{\circ} \mathrm{C}$, and at an average relative humidity of $68 \%$, varying from 65 to $71 \%$.

The chemical analyses of vitamin $\mathrm{C}$ were made by the iodate method as modified by Ballantine (1). All the analyses were determined in triplicate and the results averaged.

\footnotetext{
${ }^{3}$ Trade names are used in this publication solely for the purpose of providing specific information. Mention of a trade name does not constitute a guarantee or warranty of equipment or materials by the Agricultural Experiment Station of the University of Puerto Rico or an endorsement over other equipment or materials not mentioned.
} 


\section{RESULTS AND DISCUSSION}

The results of the experiments to determine the stability of vitamin $\mathrm{C}$ in canned sliced citron in syrup are presented in figure 1. Destruction of vitamin $\mathrm{C}$ during storage of this product seems to be higher at initial concentrations of about $110 \mathrm{mgs} / 100 \mathrm{~g}$ of product as compared to initial concentrations of $65 \mathrm{mgs} / 100 \mathrm{~g}$. During the first 4 months of storage the average destruction of vitamin $\mathrm{C}$ in the high concentration product was 4 $\mathrm{mg} / 100 \mathrm{~g} / \mathrm{month}$, while in the low vitamin $\mathrm{C}$ content product, the destruction was $3 \mathrm{mg} / 100 \mathrm{~g} / \mathrm{month}$.

Taking the whole period of storage, which was 12.7 months, the

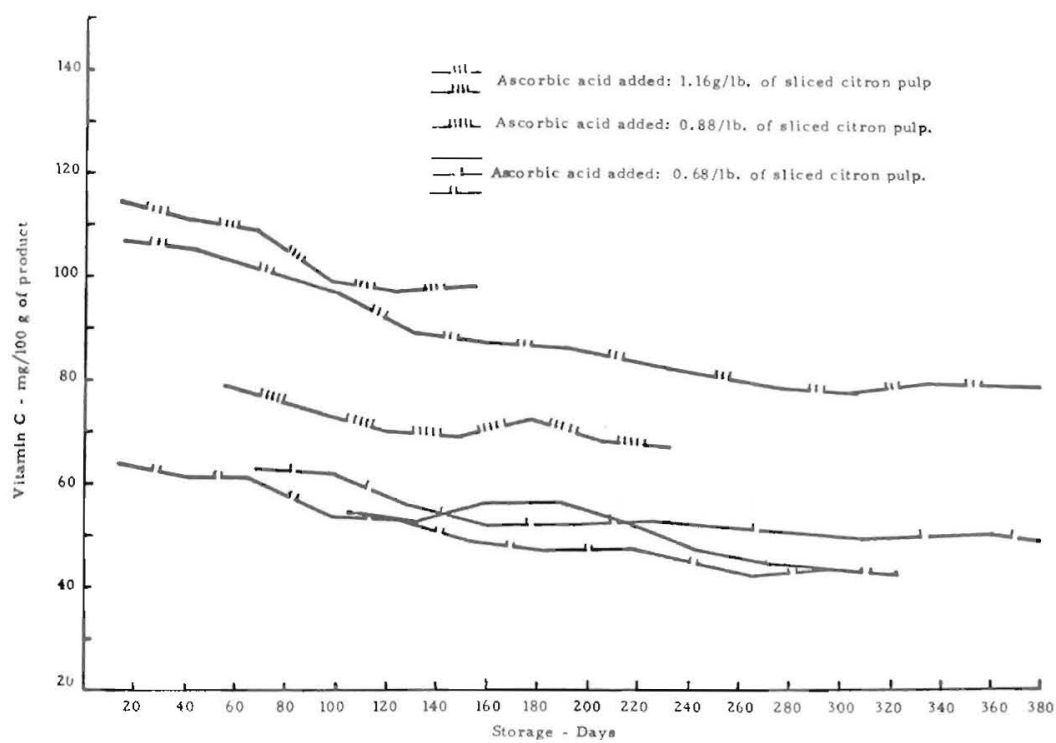

Fig. I. - Vitamin C stability during storage of canned sliced citron in syrup.

average vitamin C destruction was $2.4 \mathrm{mg} / 100 \mathrm{~g} / \mathrm{month}$ and $1.2 \mathrm{mg} / 100$ $\mathrm{g} /$ month, respectively, for the high and low vitamin content products.

Sliced citron in syrup enriched with vitamin $\mathrm{C}$ showed a vitamin preservation of 73 and $77 \%$ of the original amounts of 110 and $65 \mathrm{mg} / 100$ g, respectively.

Results of the studies carried out to determine the stability of vitamin $\mathrm{C}$ in citron fruit bar are presented in figures 2 and 3. These show a difference between the product packed in cans and packed in boxes. The vitamin $\mathrm{C}$ content of the fruit bar packed in cans seems to have an initial vitamin destruction of about $17 \mathrm{mg} / 100 \mathrm{~g}$. Since the product packed in cans and in boxes came from the same batch in each of the experiments, 


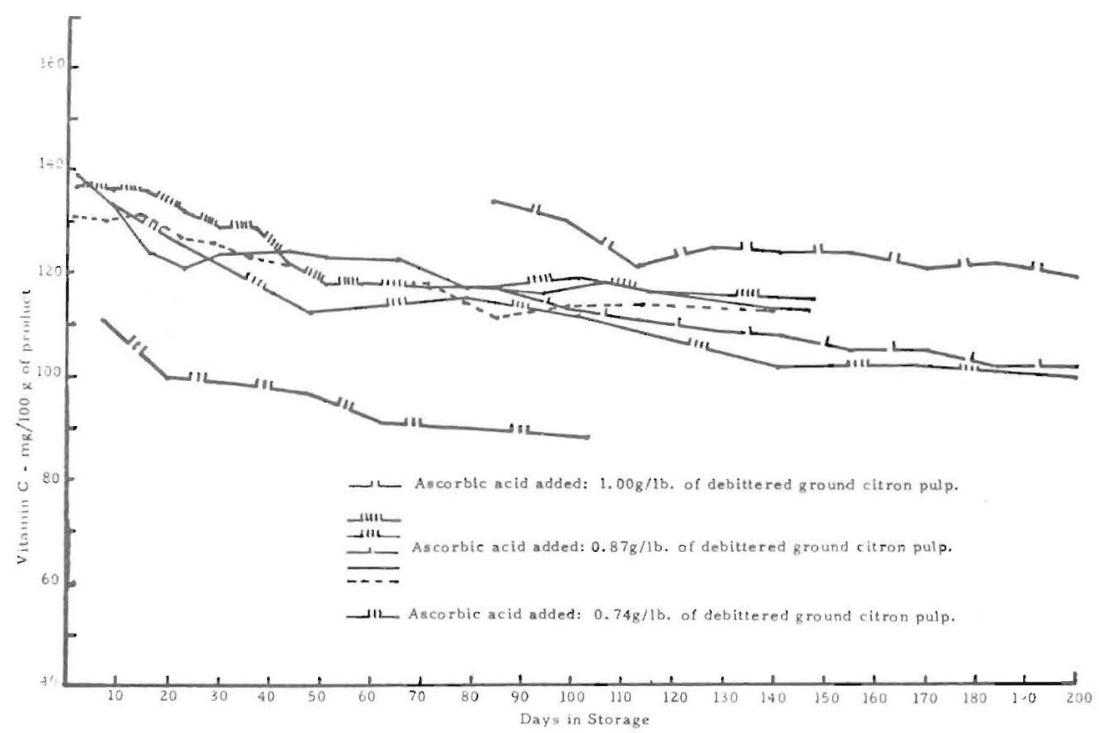

FIG. 2.-Vitamin C stability during storage of citron fruit bar packed in boxes.

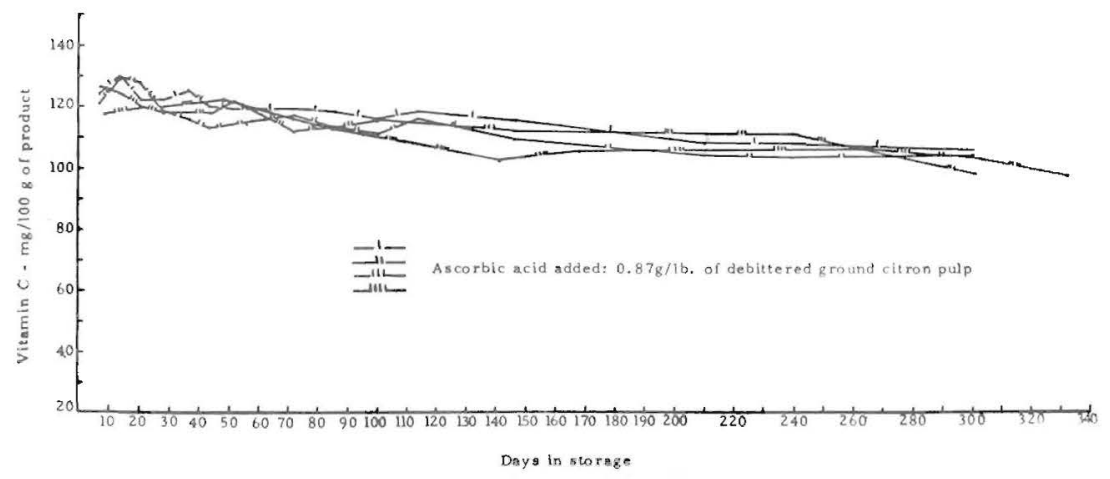

FIG.3.-Vitamin C stability during storage of canned citron fruit bar.

the only difference being the form of packaging, the immediate vitamin $\mathrm{C}$ destruction observed in the canned product is attributed to the packaging procedure.

The fruit bar packed in cans retains the heat in the product for a long period of time due to the nature of the product itself and to the form and thickness. This condition can explain the high and dramatic vitamin C destruction in the canned product at the beginning of the storage, since this vitamin is well known for its heat-labile characteristic. On the other hand the fruit bar packed in boxes is a thin slab of about $3 / 4$ in and is 
placed open in an ambient controlled chamber which provides for a faster cooling.

Aside from the initial condition in packaging and storage, where the vitamin $\mathrm{C}$ destruction trend is different, the results show that at the end of 2 months of storage the two products (canned and boxed) level off at an average of $118 \mathrm{mg} / 100 \mathrm{~g}$ of product. From this period of storage on, the stability of the vitamin $\mathrm{C}$ follows a similar trend in both products. At the end of 4 months of storage the vitamin $\mathrm{C}$ content in both products was $113 \mathrm{mg} / 100 \mathrm{~g}$ and at 5 months 110 and $109 \mathrm{mg} / 100 \mathrm{~g}$ for the canned and boxed products, respectively. Two lots of the boxed product were exhausted after 5 months of storage; therefore the study was continued with the two remaining lots up to 7 months. At this stage the vitamin $\mathrm{C}$ content for the fruit bar packed in boxes had $101 \mathrm{mg} / 100 \mathrm{~g}$ of product $73 \%$ of the original vitamin $\mathrm{C}$ content.

Fruit bar packed in cans was studied for 10 months, at the end of which a preserve with $103 \mathrm{mg} / 100 \mathrm{~g}$ of product was obtained with $84 \%$ of the original vitamin $\mathrm{C}$ content.

\section{RESUMEN}

Se estudió la estabilidad de la vitamina $\mathrm{C}$ en dulce de cidra en sirop (rebanadas) y en pasta de cidra empacada tanto en cajas como en latas.

Al cabo de 12.7 meses de almacenamiento el dulce de cidra en sirop retuvo del 73 al $77 \%$ del nivel original de vitamina C. Se encontró que durante los primeros 4 meses de almacenamiento en un dulce con $110 \mathrm{mg}$. de vitamina $C$ por $100 \mathrm{~g}$. de producto, la destrucción de esta vitamina era de aproximadamente $4 \mathrm{mg} . / 100 \mathrm{~g} . / \mathrm{mes}$, mientras que un dulce con $65 \mathrm{mg} . / 100 \mathrm{~g}$. perdió vitamina $\mathrm{C}$ a razón de $3 \mathrm{mg} . / 100 \mathrm{~g} . / \mathrm{mes}$. La destrucción de vitamina $\mathrm{C}$ durante todo el tiempo que duró el estudio fue de $2.4 \mathrm{mg} . / 100 \mathrm{~g} . / \mathrm{mes}$ para el dulce de alta concentración y de $1.2 \mathrm{mg}$./100 g./mes para el de baja concentración.

En pasta de cidra enriquecida con vitamina $C$ se demostró que la forma de empaque afecta la estabilidad de la vitamina. En lotes del producto preparados simultáneamente, en los cuales la única diferencia era la forma de empaque, se encontró que la pasta enlatada contenía menos vitamina (17 mg./100 g.) que empacada en cajas. Se encontró además, que aunque existía esta diferencia inicial, al cabo de 2 meses de almacenamiento el contenido de vitamina se niveló en los dos productos en un valor de $118 \mathrm{mg} . / 100 \mathrm{~g}$. A los 4 meses la vitamina se niveló en los dos productos en un valor de $118 \mathrm{mg} . / 100 \mathrm{~g}$. A los 4 meses la vitamina $\mathrm{C}$ en los dos productos (enlatado y en cajas) era de $113 \mathrm{mg} . / 100 \mathrm{~g}$. y al cabo de 5 meses era de 110 y $109 \mathrm{mg} . / 100 \mathrm{~g}$. , respectivamente.

Al finalizar el estudio de 7 meses, la pasta de cidra en caja retuvo aproximadamente el $73 \%$ del contenido de vitamina original, mientras que en latas, al finalizar 10 meses de estudio, retuvo $84 \%$.

\section{LITERATURE CITED}

1. Ballantine, R., Determination of ascorbic acid in citrus juices, Ind. Eng. Chem., Anal. Ed., 13: 89-90, 1941.

2. Bissett, O. W., and Berry, R. E., Ascorbic acid retention in orange juice as related to container type, J. Food Sci. 40: 178-80, 1975.

3. Bolin, H. R. an tafford, A. E., Effect of processing and storage on provitamin A and vitamin C in apricots, J. Food Sci., 39: 1034-6, 1974. 
4. Cancel, L. E., Hernández-Torres, I., Hernández, E. R. de, and Rosario-Hernández, J. A., Método para preparar el dulce de cidra en almíbar, Publ. 84, Est. Exp. Agr., Univ. P.R., 1974.

5. Hernández, E. R. de, and Rosario-Hernández, J. A., Método para preparar pasta de cidra, Publ. 96, Est. Exp. Agr., Univ. P.R., 1975.

6. Jensen, A, Tocopherol content of seaweed and seameal, 3. Influence of processing and storage on the content of tocopherol, carotenoids and ascorbic acid in seaweed meal. $J$. Sci. Food Agr. 20: 622-4, 1967.

7. Karel, M., and Nickerson, J. T. R., Effect of relative humidity, air, and vacuum on browning of dehydrated orange juice, Food Technol. 18: 1214-8, 1964.

8. Lee, S. H., and Lubuza, T. P., Destruction of ascorbic acid as a function of water activity, J. Food Sci. 40: 370-3, 1975.

9. Vojnovich, C., and Pfeifer, V. P., Stability of ascorbic acid in blends with wheat flour, CSM and infant cereals, Cereal Sci. Today 19: 317-20, 1970. 